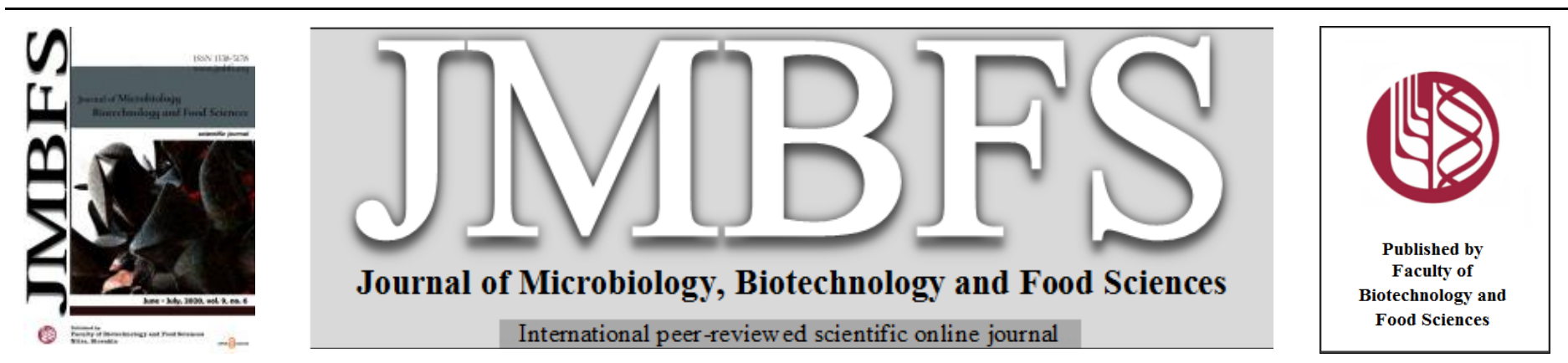

\title{
PROCESSING EFFECTS ON ANTI-NUTRITIONAL FACTORS, PHYTOCHEMICALS, AND FUNCTIONAL PROPERTIES OF HORSE GRAM (MACROTYLOMA UNIFLORUM) FLOUR
}

\author{
Pravin Ojha ${ }^{*}$, Yashoda Bhurtel ${ }^{2}$, Roman Karki ${ }^{1}$, Ujjwol Subedi ${ }^{1}$ \\ Address(es): Mr. Pravin Ojha, M.Tech (Food), \\ ${ }^{1}$ Food Research Division, Nepal Agricultural Research Council, Khumaltar, 44700 and Lalitpur, Nepal, +977-9851023022. \\ ${ }^{2}$ Department of Food Technology, National College of Food Science and Technology, Khusibu, 44611 and Kathmandu, Nepal.
}

*Corresponding author: projha84@gmail.com

doi: $10.15414 / j m b f s .2020 .9 .6 .1080-1086$

\section{ARTICLE INFO}

Received 18.9. 2018

Revised 16. 1. 2020

Accepted 20. 1.2020

Published 1. 6. 2020

Regular article

OPEN $\partial$ ACCESS

\begin{abstract}
The work aimed to study the effect of processing methods, namely soaking, fermentation, germination, and roasting on anti-nutritional compounds, phytochemicals, and functional property of horse gram flour. Horse gram was soaked in water (1:3 w/v) up to $24 \mathrm{~h}$ to get soaked horse gram. While after $12 \mathrm{~h}$ soaking in water $(1: 2 \mathrm{w} / \mathrm{v})$ seeds were ground into a slurry and allowed to ferment naturally for 48 $\mathrm{h}$ in a sterile flask. The soaked seeds after $24 \mathrm{~h}$ were spread in a muslin cloth to germinate for $72 \mathrm{~h}$ at $27 \pm 3^{\circ} \mathrm{C}, 90 \% \mathrm{RH}$. The unsoaked seeds were roasted on low flame for $10 \mathrm{~min}$ in an iron pan. Treated horse gram seeds were then dried in a cabinet drier at $50^{\circ} \mathrm{C}$ for $24 \mathrm{~h}$ except for roasted horse gram, and milling was done to get the flour. Anti-nutritional factors were significantly reduced after fermentation, particularly phytic acid, tannin and oxalate content were reduced by $69.5,69.3$, and $66.7 \%$ respectively while reduction during germination was 61.6, 54.6 and $61.6 \%$ respectively. But, soaking and roasting reduced polyphenols and flavonoids content. Meanwhile, increment in phytochemicals was observed during germination (26\% and 30.7\%) and fermentation (86.9\% and 53.8\%) respectively. In the case of antioxidant content, it decreased during soaking (28.7\%) while increases during roasting (29.1\%), germination (51.6\%) and fermentation (59.9\%). Bulk density and viscosity decreased during treatment, while water absorption capacity and oil absorption capacity increased in treated horse gram flour. The study showed that germination and fermentation can produce a significant reduction in the anti-nutritional factor and a considerable rise in bioactive components along with the improved functional property of horse gram flour as compared to the untreated one.
\end{abstract}

Keywords: Germination, Fermentation, Phytic acid, Antioxidant activity, and Oil absorption capacity

\section{INTRODUCTION}

Horse gram (Macrotyloma uniflorum), unexploited food legume, is cultivated in dry areas of land globally. Reports have suggested Australia, east and northeast Africa, Burma, India, Nepal, and Sri Lanka are the leading producers of horse gram (Sodani et al., 2005; Krishna 2010, Durga 2012). It is also called Gahat in Nepal, and production was $5662 \mathrm{MT}$ with a yield of $918 \mathrm{Kg} / \mathrm{Ha}$ (Moktan and Ojha, 2016, MoAD, 2016). In Nepal, the horse gram can be considered as an inexpensive source of protein (20\%). Like other legumes, it is deficient in methionine and tryptophan but can be regarded as a good source of calcium, iron, and vitamins like thiamin, riboflavin, niacin, and L-ascorbic acid (Sodani $\boldsymbol{e t} \boldsymbol{a l}$., 2005). It is noteworthy to mention that because of the higher content of dietary fibre, it might induce, beneficial effects on the intestine and colon (Sreeram $\boldsymbol{e t}$ al., 2012). Despite the presence of proper nutrients, utilization of horse gram is limited which might be due to the presence of anti-nutritional factors present within the gram.

These anti-nutritional compounds have been reported to reduce the absorption of various minerals like calcium, iron, zinc, phosphorus, and magnesium by forming soluble or insoluble salt, eventually leading to decrease digestibility of protein (Emmanbux and Taylor, 2003; Melaku et al., 2005; Ogunkoya et al., 2006; Rodríguez et al., 2013).

Many authors have reported that different processing treatments like soaking, roasting, germination, and fermentation can decrease the anti-nutritional factors in legumes (Ahmed et al., 2006; Akande and Fabiyi, 2010; Moktan and Ojha 2016; Ojha et al., 2018). Sreeram et al (2008) reported that processing like soaking, roasting, fermentation, etc. reduced the anti-nutritional components significantly. No work has been reported to date on the effect of processing conditions on the Nepalese horse gram. Hence, it will be beneficial to see the impact of different processing conditions on the anti-nutritional factors of horse gram grown in Nepal.
Literature suggested that horse gram is a rich source of functional compounds like polyphenols, flavonoids, and tannins. Polyphenols and flavonoids show high antioxidant activity than that of essential vitamins (Sreeram et al., 2012). Bhokre et al. (2015) evaluate the functional properties of five different genotypes of horse gram in India, while Sreeram et al. (2008) demonstrate that processing produces a significant change in the functional property. Processing like soaking, roasting, germination, and fermentation induce changes in protein, starch, their interaction, and alignment, which affect the functional properties of flour (Oti and Akobundu, 2008; Odedeji and Oyeleke, 2011; Onuegubu et al., 2013). Functional properties evaluation is essential to assess its compatibility with different product formulation like baby food, soup thickener, bakery product, etc.

Thus, due to the presence of anti-nutritional factors and lack of product diversification, there is lack of proper market for horse gram. Further processing not only reduces the anti-nutritional factor (ANFs) but also affects the bioactive component and functional property of flour. So, it is necessary to identify a suitable processing method, which not only reduces ANFs but also a technique that results in a minimum change in the bioactive component. Hence, any technique that can eliminate or inactivate such anti-nutritional components is necessary to improvise the nutritional quality of horse gram. Further, the gram can be promoted as human food even in remote areas of Nepal. Similarly, this work will help to identify the best processing method which will facilitate in enhancing bioactive components positively. Likewise, the functional property will help to identify the potentiality of horse gram flour in different food applications. The objective of this research was to evaluate the changes in antinutritional components, phytochemicals, anti-oxidant property, and functional property due to different processing treatments. 


\section{MATERIALS AND METHODS}

\section{Materials}

Horse gram (variety not registered) was purchased from the local market of Kathmandu, Nepal. The legume was first sorted to remove deformed, broken horse gram, dust, sand, stones and other foreign materials like straws. Clean horse gram was stored in air-tight containers at room temperature until processing. The analytical grade chemicals used for the analysis were of analytical grade. 2, 2-diphenyl-1-picrylhydrazyl (DPPH) (purity $\geq 85 \%)$, Folinciocalteu reagent (normality $2 \mathrm{~N}$ ), gallic acid (purity: 99.5\%), and methanol (purity $99.5 \%$ ) were obtained from Sigma-Aldrich Company (Germany), Finar Limited (India), LOBA Chemie (India) and Fisher Scientific (India) respectively. Sodium tungstate (purity 98\%) and phosphomolybdic acid (purity 98\%) for Folin-Denis reagent, Sodium hydroxide (purity 97\%), sulphuric acid (purity 98\%), tannic acid (purity 99.99\%), sodium hypochlorite (purity 99\%), and potassium permanganate (purity 99\%) were acquired from Fisher Scientific, India.

\section{Research Design and Data Analysis}

The research design adopted was a completely randomized design with five treatments with triplicate analysis for each parameter. IBM SPSS statistics version 20 and Microsoft Office Excel 2007 was used for the statistical analysis and data interpretation. The means of data were compared by one-way Analysis of variance (ANOVA) using SPSS version 20 programming at a 5\% level of significance by using the Tukey test.

\section{Preparation of Horse Gram Flour}

Horse gram was subjected to four treatments, namely soaking, roasting, fermentation, and germination, (as shown in Figure 1)

a. Soaking: The horse gram $(500 \mathrm{~g})$ was soaked in water $(1: 3 \mathrm{w} / \mathrm{v})$ for $24 \mathrm{~h}$. After, $24 \mathrm{~h}$ the seeds were rinsed with clean water to produce soaked grain (Moktan and Ojha, 2016).

b.Roasting: Clean horse gram $(500 \mathrm{~g})$ was roasted on low flame $\left(160^{\circ} \mathrm{C}\right)$ for 10 min in an iron pan $(1.5 \mathrm{~L})$ till it changed to light brown colour and developed roasted flavour.

c. Germination: $500 \mathrm{~g}$ horse gram was soaked in water $(1: 3 \mathrm{w} / \mathrm{v})$ at $27 \pm 3^{\circ} \mathrm{C}$ for 12 $\mathrm{h}$. The excess water was drained and the sample was further rinsed with potable water and was allowed to germinate under a wet muslin cloth for $72 \mathrm{~h}$ at $27 \pm 3^{\circ} \mathrm{C}$, 90\% RH (Wedad et al., 2008). The average length of the sprout was $5 \mathrm{~mm}$.

d. Fermentation: Horse gram seeds were treated with sodium hypochlorite $(0.07 \% \mathrm{v} / \mathrm{v})$ solution for $30 \mathrm{~min}$ to remove the surface contaminants. Then, the seeds were washed with distilled water and drained well. Horse gram was soaked for $12 \mathrm{~h}$ and ground into a slurry $(1: 2 \mathrm{w} / \mathrm{v})$ and natural fermentation was carried out for $48 \mathrm{~h}$ in a sterile flask (Wedad et al., 2008). The $\mathrm{pH}$ drop from 6.4 to 4.6 .

e. A control flour sample was produced without any treatment for the preparation of horse gram flour.

Except for roasted one, all the processed seeds were dried in a cabinet drier at $50 \pm 5^{\circ} \mathrm{C}$ for $24 \mathrm{~h}$.

The dried horse gram was ground in a grinder (Ameet IS: 4520, India). The flour was sieved by the laboratory sieve of 40 mesh size. The grits were removed and the sieved powder was packed in an airtight plastic pouch $(45 \mu \mathrm{m})$ till analysis was completed. The simplified diagram is shown in figure 1 .

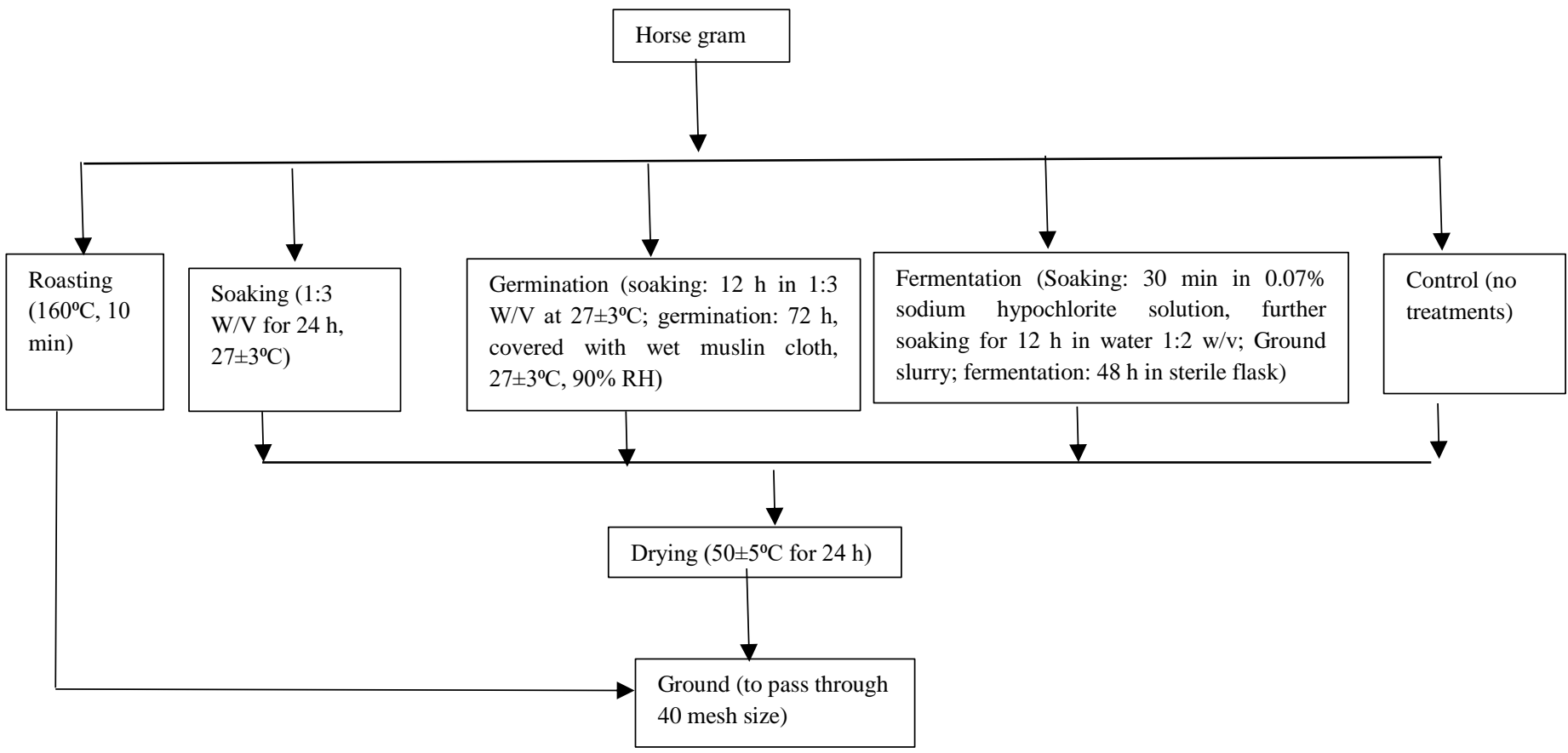

Figure 1 Diagram representing the processing plans for the production of horse gram flour

\section{Chemical Analysis}

\section{Preparation of extract for tannin and bioactive components}

The extract for bioactive component estimation was prepared by the method adopted by Sigdel $\boldsymbol{e t}$ al. (2018) with slight modification. The extracts were prepared by extracting the horse gram flour $(1 \mathrm{~g})$ with methanol $(95 \%)$ and filtered (Whatman no. 1) to prepared $100 \mathrm{~mL}$ extract. Initially, $30 \mathrm{~mL}$ methanol was added in a conical flask containing $1 \mathrm{~g}$ horse gram flour and shakes for 30 min in a shaker and filtered. The residue was extracted similarly twice, and the final volume was made $100 \mathrm{~mL}$. The extracts were stored in a brown reagent bottle at $4 \pm 1^{\circ} \mathrm{C}$

\section{Determination of Anti-nutritional Factors}

a. Phytic acid: Phytic acid was determined by the method described by Reddy (2001).The phytate converted to ferric phytate by treating with ferric chloride. The ferric phytate precipitate was converted to ferric hydroxide by addition of sodium hydroxide, which is further converted to ferric nitrate by treating with nitric acid. The absorbance was then measured through the UV-Vis Spectrophotometer (GENESYS 10S Vis Spectrophotometer, Thermo Scientific, Germany) at $410 \mathrm{~nm}$. The calculation was based on the determination of iron, and phosphorous was calculated from the ratio $\mathrm{Fe}: \mathrm{P}=4: 6$. From phosphorous, phytic acid (inositol hexaphosphate) was calculated.

b. Tannin content: Tannin content was determined by the method described by Ojha et al. (2018) with slight modification using tannic acid instead of gallic acid. The sample extract was reacted with Folin-Denis reagent followed by saturated carbonate solution, and the absorbance was measured through UV-Vis Spectrophotometer at $760 \mathrm{~nm}$ wavelength after $90 \mathrm{~min}$ of incubation at dark. A similar process was carried out for a tannic acid standard solution, and the result was expressed as mg TAE(tannic acid equivalent)/g.

c: Oxalate content: Oxalate content was determined by titrating acidified sample solution $\left(3 \mathrm{M} \mathrm{H}_{2} \mathrm{SO}_{4}\right)$ with a standard $\mathrm{KMnO}_{4}$ solution as described by Chinma and Igyor (2007).

\section{Determination of Bioactive Compounds}

The total polyphenol content of the prepared extract was estimated by treating with Folin- Ciocalteau solution as per Mahdavi $\boldsymbol{e t}$ al. (2011) and by measuring absorbance through UV-Vis Spectrophotometer at $760 \mathrm{~nm}$ and using gallic acid solution for the standard curve.

The total flavonoid content (TFC) of the prepared extract was determined as per Chang et al. (2002) with slight modifications using the aluminium chloride assay through UV-Vis Spectrophotometer at $510 \mathrm{~nm}$. The calibration standard curve 
was prepared by preparing gallic acid solutions. Both polyphenols and flavonoids were expressed as mg GAE (gallic acid equivalent)/g.

The antioxidant activity was determined by the DPPH radical scavenging method as described by Sigdel $\boldsymbol{e t}$ al. (2018) with slight modifications. DPPH solution $(0.004 \% \mathrm{w} / \mathrm{v})$ was prepared in $95 \%$ methanol. The equal volume $(10 \mathrm{ml})$ of extract and freshly prepared DPPH $(0.004 \% \mathrm{w} / \mathrm{v})$ were mixed, and the tubes were incubated at room temperature in the dark for $30 \mathrm{~min}$, the absorbance was taken at $517 \mathrm{~nm}$ using a UV-Vis spectrophotometer. 95\% of methanol was used as a blank.

The scavenging activity of the extract against the stable DPPH was calculated using the following equation,

$$
\text { Scavenging activity }(\%)=(A-B) / A \times 100
$$

Where A is the absorbance of DPPH and B is the absorbance of DPPH and the extract combination.

\section{Determination of functional properties}

Packed bulk density: The bulk density was determined according to the method described by Kanpairo et al. (2012) with some modification. Twenty-five grams of sample was gently filled into a dried $50 \mathrm{~mL}$ graduated cylinder, tapped the cylinder gently for 25 times. The volume of the powder was recorded. The packed bulk density was calculated as the following relationship.

\section{Packed Bulk density = weight of powder/volume of powder}

Viscosity: The method for viscosity determination was carried out per Nwosu (2011). Ten percent of the flour suspension in distilled water was mechanically shaken for $2 \mathrm{~h}$, and the viscosity of the suspension was measured by using Ostwald viscometer.

Water absorption capacity: Water absorption capacity was determined as described by Nwosu et al. (2014) with slight modification. One g of horse gram flour sample was weighted separately in the clean and dry tube and $10 \mathrm{~mL}$ water was added. It was then centrifuged at $2000 \mathrm{rpm}$ for $15 \mathrm{~min}$. The tube with powder was reweighed after discarding the supernatant. The gain in mass with respect to initial mass was calculated as the water absorption capacity of the flour sample.

Oil absorption capacity: The method described by Onuegbu $\boldsymbol{e t}$ al. (2013) was adopted with slight modification for oil absorption capacity. One gram of horse gram flour was weighed separately and introduced into clean centrifuge tubes of known weights. Sunflower oil (Sp. gr. 0.92) was mixed with the flour in each tube and centrifuged at $2000 \mathrm{rpm}$ for $20 \mathrm{~min}$. The supernatant was discarded and the tube was reweighted. The gain in mass with respect to initial mass was calculated as the oil absorption capacity of horse gram flour.

\section{RESULTS AND DISCUSSION}

This work was carried to evaluate the changes in anti-nutritional components, phytochemicals, anti-oxidant property, and functional property of flour obtained after different processing treatments on the horse gram.

\section{Anti-nutritional Factors}

The phytate content of control whole horse gram was found to be $10.22 \pm 0.70$ $\mathrm{mg} / \mathrm{g}$. The Phytate, tannin and oxalate content of horse gram flour with the soaking, roasting, germination, and fermentation treatments are presented in Figure 2. The phytate content of horse gram flour was reduced by $18.1 \%, 22.4 \%$, $61.6 \%$ and $69.5 \%$ by soaking, roasting, germination, and fermentation respectively. The tannin content of the whole horse gram was found to be $11.75 \pm 0.10 \mathrm{mg} / \mathrm{g}$. The tannin content of soaked, roasted, germinated and fermented horse gran flour was reduced by $22.55 \%, 28 \%, 54.6 \%$, and $69.36 \%$ respectively. The oxalate content of whole horse gram flour was found to be 3.13 $\mathrm{mg} / \mathrm{g}$. The oxalate content of horse gram flour was reduced by $23.32 \%, 22.36 \%$, $61.66 \%$, and $66.77 \%$ by treatments (soaking, roasting, germination, and fermentation) respectively. The result is shown in figure 1 and the values were significantly different $(\mathrm{p}<0.05)$.

Sreerama et al. (2008) found phytic acid $7.48 \mathrm{mg} / \mathrm{g}$ in horse gram, less than the result obtained. Bhokre et al. (2015) reported the tannin content of horse gram in the range of $1.09-1.68 \mathrm{mg} / \mathrm{g}$, which differs from the result obtained. The variety difference might be the reason. Huma et al. (2008) also reported a decrease in phytic acid and tannin content of kidney bean, lentil, chickpea, and white gram during soaking and cooking. Dave $\boldsymbol{e t}$ al. (2008) reported a decrease in the phytate content of cowpea, horse gram, moth bean, mungbean, soybean and pearl millet by heating and germination. Agume $\boldsymbol{e t}$ al. (2017) reported that roasting and soaking decrease phytic acid significantly in soybean flour but only roasting produces a significant change in tannin. Afam et al. (2016) reported a decrease in phytate, oxalate, and tannin of mungbean after germination. Babalola and Giwa (2012) reported a decrease in tannin, phytate, and oxalate in fermented soybean than unfermented ones.

Ojha and Moktan (2016) also reported a decrease in phytic acid, tannin, and oxalate during germination of horse gram. Ojha et al. (2018) reported a decrease in phytic acid, tannin, and oxalate during germination and fermentation. The reduction of phytic acid, tannin, and oxalate in horse gram flour can be attributed to the leaching loss of these components in water during soaking. Endogenous phytase activity during soaking was responsible for decreased phytic acid (Lestienne et al., 2005). Denaturation and formation of insoluble complexes of phytate, tannin, and oxalate during roasting may be responsible for the reduction of these anti-nutrients compound in horse gram flour (Siddhuraju and Becker, 2001; Nithya et al., 2006; Makande et al., 2016).

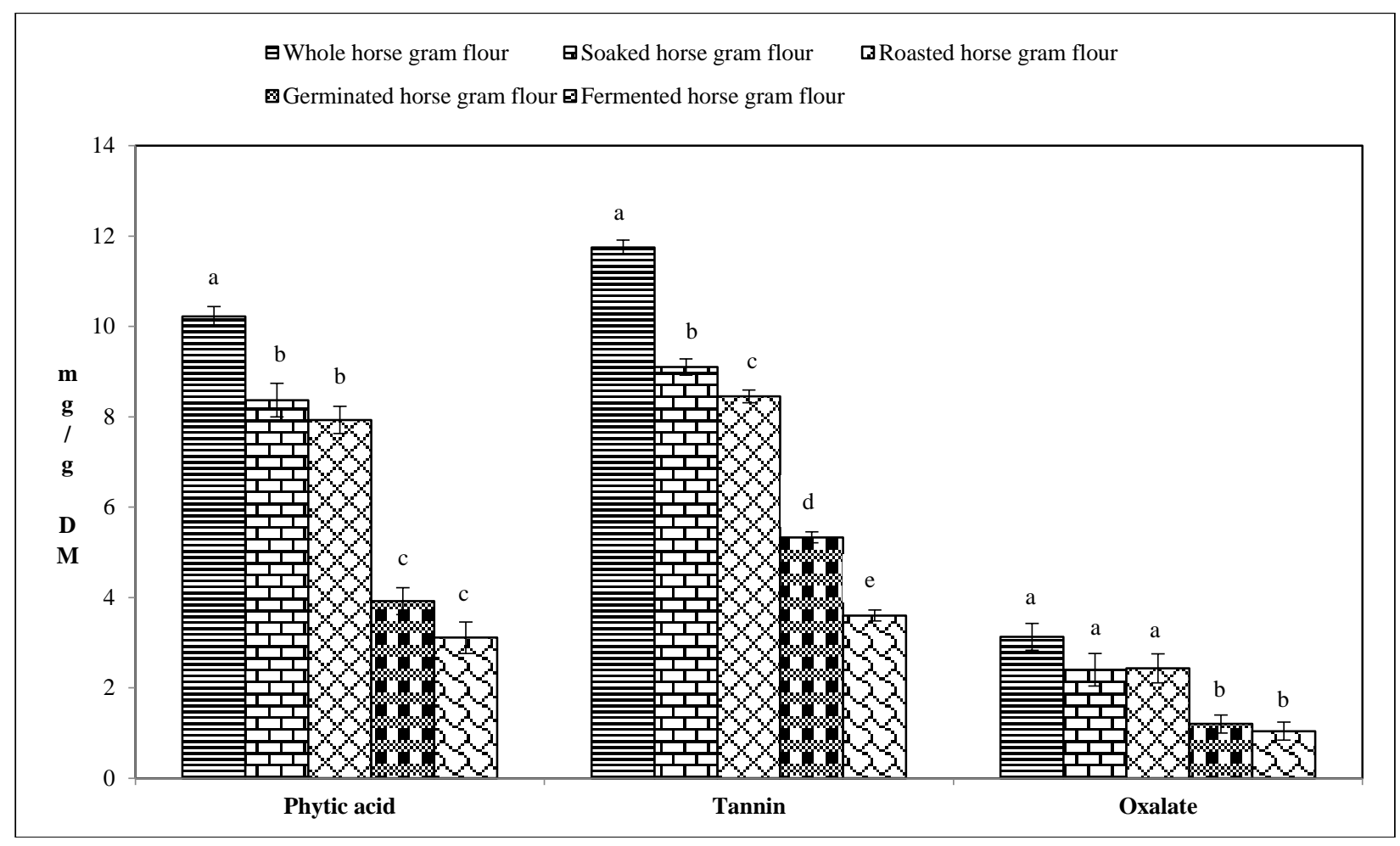

Figure 2 Phytate, tannin and oxalate content of horse gram flour with the soaking, roasting, germination, and fermentation treatments

The vertical bar with the error bar represents the mean with standard deviation. Different letters in the same cluster indicate values are significantly different ( $<<0.05$ ) 
Authors (Greiner et al., 2000; Agostini et al., 2010) suggested that there is an increased activity of enzymes. These enzymes such as Phytase may become active during germination. The utilization of phosphorous of phytate for inorganic phosphorous and leaching loss during soaking before germination might be responsible to reduce phytic acid during germination (Schons $\boldsymbol{e t}$ al., 2012). The activity of polyphenol oxidase was induced by roasting, which results in reduce tannin content (Brito et al., 2002; Charlton et al., 2002). Reduction of tannin content in germinated horse gram flour can be attributed to the effect of polyphenol oxidase induced by soaking and formation of complexes during germination (Saxena et al., 2003; Shimelis and Rakshit, 2007; Khandelwal $e$ al., 2010). During germination, oxalate oxidase might split oxalic acid and further leaching during soaking reduced oxalate content in germinated horse gram flour.

The maximum reduction was found in fermented horse gram flour, which might be due to phytase activity of lactic acid bacteria, low $\mathrm{pH}$ and high activity of phytase enzyme in low pH (Sreeramulu et al., 1996; Valencia et al., 1999). The tannin acyl hydrolases produced by microbes were responsible for reduced tannin content in fermented horse gram flour (Schons $\boldsymbol{e t}$ al., 2012). The reduction of oxalate during fermentation might be due to the utilization of oxalate as the carbon source by microbes during fermentation and indirect effect of phytase activity (Weese et al., 2004; Simpson et al., 2009)

\section{Bioactive components (Polyphenols and flavonoids) and antioxidant activity}

The polyphenols and flavonoid content of whole horse gram was found to be $4.6 \pm 0.30$ (mg GAE/g) and $3.9 \pm 0.10(\mathrm{mg} \mathrm{GAE} / \mathrm{g})$ respectively. Polyphenols decreased by $19.5 \%$ and $28.3 \%$ while flavonoids decreased by $33.3 \%$ and $48.7 \%$ during soaking and roasting respectively. Similarly, polyphenols increased by
$26.1 \%$ and $86.9 \%$ whereas flavonoids increased by $30.7 \%$ and $53.84 \%$ by germination and fermentation respectively. The antioxidant activity (AOA) of whole horse gram was found to be $52.68 \pm 2.24 \mathrm{DPPH} \%$ inhibition, which decreased during soaking $(28.77 \%)$ while increased during roasting $(29.13 \%)$, germination $(51.61 \%)$ and fermentation $(59.92 \%)$. The bioactive components and antioxidant activity of horse gram flour are shown in Figures 2 and 3 respectively and the values were significantly different at $\mathrm{p}<0.05$.

An increase in polyphenols and flavonoids content during germination and fermentation has been reported by many authors (Hiran et al., 2011; Wu et al., 2011). Ojha and Moktan (2016) found that there was a significant increase in polyphenols and antioxidant activity during germination. Khang et al. (2016) reported an increase in phenolic compounds and antioxidant activity of soybean, black bean, mung bean, white cowpeas and peanuts induced by germination. Tarzi et al. (2012) reported an increase in phenolic compounds and antioxidant activity in germinated chickpea. Lopez-Amoros $\boldsymbol{e t}$ al. (2006) reported a positive influence on phenolic compounds and antioxidant activity of beans and peas but has a negative influence in the case of lentils due to germination. Oboh $\boldsymbol{e t}$ al. (2009) reported an increase in phenolic components and antioxidant activity of pigeon pea and kidney bean due to fermentation. Dordevic et al. (2010) reported an increase in total polyphenol and antioxidant of buckwheat, wheat, barley and rye due to fermentation.

Leaching out of soluble phenolic components and flavonoids in soaked water might be responsible for the loss of phenolic components in soaked horse gram flour. Thermal degradation of phenolics and flavonoids during roasting decreased these bioactive components (Randhir et al. 2008; Zhang et al., 2010; Zhu et al., 2010)

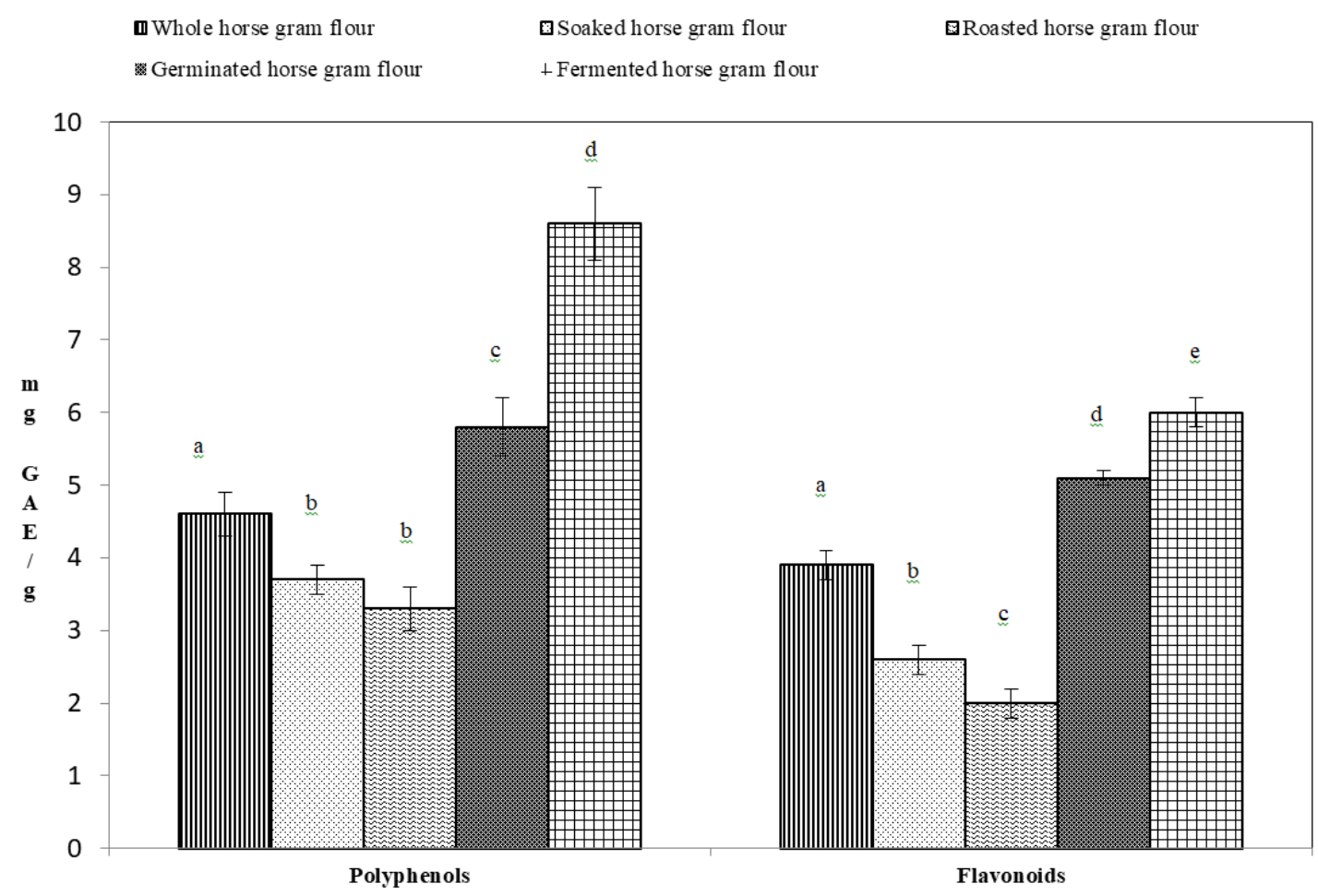

Figure 3 Effect of processing (soaking, roasting, germination, and fermentation) on the polyphenols and flavonoids of horse gram flour The vertical bar with the error bar represents the mean with standard deviation. Different letters in the same cluster indicate values are significantly different $(\mathrm{p}<0.05$ ) 


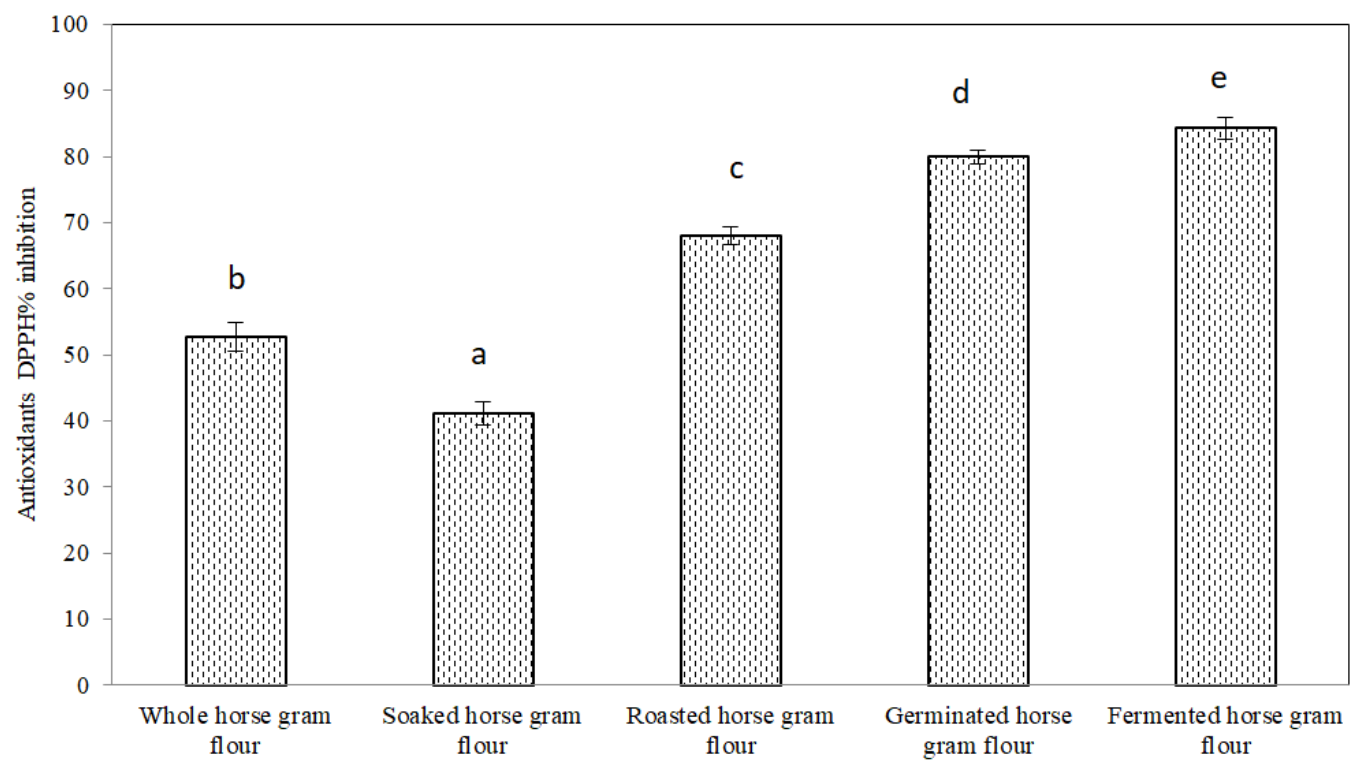

Figure 4 Effect of processing (soaking, roasting, germination, and fermentation) on the polyphenols and flavonoids of horse gram flour The vertical bar with the error bar represents the mean with standard deviation. Different letters in bar indicate values are significantly different ( $\mathrm{p}<0.05$ ). Anti-oxidant activity (\%) was shown by $10 \mathrm{mg} / \mathrm{mL}$ of extract

The increased polyphenol oxidase activity responsible for the release of the bounded form of phenolic in cellular constituents and secondary metabolites like anthocyanin and flavonoids were produced increased the polyphenol and flavonoid in germinated horse gram flour (Randhir et al., 2004; Vadivel et al. 2011). Proteolytic enzymes from starter culture break down complexes of polyphenol into soluble and free phenols and acidity increased during fermentation may liberate bound free flavonoids, might be responsible for increased polyphenols and flavonoids in fermented horse gram flour (Shrestha $\boldsymbol{e t}$ al., 2010; Ademiluyi and Oboh, 2011; Ojha and Moktan, 2016).

Anesini et al. (2008) reported that polyphenol has a strong and positive correlation with antioxidant activity so antioxidant activity reduced in soaked horse gram flour. However, dry roasting resulted in a significant increase in antioxidant activity despite reduced polyphenol content. This might be due to the formation of browning compounds like amino reductones and carbonyls, which also reduced the colour of the DPPH solution as reviewed by Woffenden $\boldsymbol{e t}$ al. (2002). During the course of germination and fermentation, several biochemica processes initiate like phytase activity and synthesis of polyphenols and flavonoids, which increased the antioxidant activity (Hiran et al., 2011; Tiwari et al., 2013). The increment of polyphenols and flavonoids in germinated and fermented horse gram flour can also be attributed to increased antioxidant activity as reviewed by Anseini et al. (2008) and Khang et al. (2016).

\section{Functional properties of horse gram flour}

The bulk density and viscosity of soaked, roasted, germinated and fermented horse gram flour was significantly lower $(\mathrm{p}<0.05)$ than that of untreated horse gram flour while WAC and OAC increased after treatment as shown table 1 and the values were significantly different at p,0.05.

Ojha et al. (2018) also reported a decrease in bulk density and viscosity of germinated and fermented sorghum flour and an increase in WAC and OAC of sorghum flour after germination and fermentation. Desalgn (2015) also reported a reduction in bulk density and increased WAC and OAC of soaked and germinated chickpea flour. Ogodo et al. (2017) reported a decrease in bulk density and water holding capacity but oil absorption capacity was increased in fermented sorghum flour. Khan and Saini (2016) reported water absorption capacity and bulk density were increased in roasted flax seed flour while oil absorption capacity was decreased. Agume et al. (2017) reported roasting and soaking induce a decrease in bulk density and viscosity of soybean flour. Chinma et al. (2010) reported a decrease in bulk density and increase in OAC of tiger nut flour after germination.

Reduction in bulk density might be due to starch modification, reduction in denser compounds to simpler ones (breaking of starch) during processing and dispersibility of the processed flour (Gernah et al., 2011; Ogori and Alimi, 2013). The reduced bulk density of flour can be essential to prepare infant foods and complementary foods. The difference in viscosity might be due to the weakness of the intermolecular network of protein and carbohydrate which may cause the flour granules to fall apart when gelatinized in hot water forming a paste of low relativity viscosity and due to the reduction of carbohydrate and protein interaction (Ocheme et al., 2015). Nutrient-dense products can be prepared as a high amount of food is required to achieve the same viscosity for baby food.
High water absorption capacity has importance in the stabilization of starch against syneresis and the development of ready-to-eat foods due to increased cohesiveness. Reduction of carbohydrate and protein interaction may expose more hydrophilic constituents especially protein (Echendu et al., 2004; Onuegbu et al., 2013). The observed variation in water absorption capacity among the flours may be due to the degree of interaction of the protein with water and conformational characteristics of protein (Butt and Batool, 2010). It can be assumed that the polar amino acid residues of proteins with a strong attraction for water molecules could have increased the water absorption capacity of germinated horse gram flour (Sreerama et al, 2012). The mechanism of fat absorption is mainly concerned with the physical entrapment of oil and the binding of fat to the apolar chain of protein (Awolu et al., 2017). Agrawal et al. (2013) stated that germination-induced increased oil absorption capacity might be due to the solubilization and dissociation of proteins leading to exposure of nonpolar constituents from within the protein molecule. Increased fat absorption best suited the product to prepare meat extenders as it improves the flavor and mouthfeel (Onuegbu et al., 2013).

Table 1 Effect of processing (soaking, roasting, germination, and fermentation) on functional properties of horse gram flour

\begin{tabular}{lcccc}
\hline Sample & $\begin{array}{c}\text { Bulk density } \\
(\mathrm{g} / \mathrm{mL})\end{array}$ & $\begin{array}{c}\text { Viscosity } \\
(\mathrm{cP})\end{array}$ & $\begin{array}{c}\text { Water } \\
\text { absorption } \\
\text { capacity }\end{array}$ & $\begin{array}{c}\text { Oil } \\
\text { absorption } \\
\text { capacity }\end{array}$ \\
\hline $\begin{array}{l}\text { Whole horse } \\
\text { gram flour }\end{array}$ & $0.72 \pm 0.01^{\mathrm{a}}$ & $0.92 \pm 0.02^{\mathrm{a}}$ & $1.17 \pm 0.01^{\mathrm{a}}$ & $1.96 \pm 0.02^{\mathrm{a}}$ \\
$\begin{array}{l}\text { Soaked horse } \\
\text { gram flour }\end{array}$ & $0.67 \pm 0.01^{\mathrm{b}}$ & $0.76 \pm 0.01^{\mathrm{b}}$ & $1.22 \pm 0.01^{\mathrm{b}}$ & $2.08 \pm 0.04^{\mathrm{b}}$ \\
$\begin{array}{l}\text { Roasted horse } \\
\text { gram flour }\end{array}$ & $0.63 \pm 0.01^{\mathrm{c}}$ & $0.84 \pm 0.01^{\mathrm{c}}$ & $1.28 \pm 0.01^{\mathrm{c}}$ & $2.37 \pm 0.01^{\mathrm{c}}$ \\
$\begin{array}{l}\text { Germinated } \\
\text { horse gram } \\
\text { flour }\end{array}$ & $0.61 \pm 0.01^{\mathrm{c}}$ & $0.76 \pm 0.01^{\mathrm{b}}$ & $1.61 \pm 0.01^{\mathrm{d}}$ & $3.02 \pm 0.02^{\mathrm{d}}$ \\
$\begin{array}{l}\text { Fermented } \\
\text { horse gram } \\
\text { flour }\end{array}$ & $0.59 \pm 0.01^{\mathrm{d}}$ & $0.80 \pm 0.01^{\mathrm{d}}$ & $1.41 \pm 0.01^{\mathrm{e}}$ & $2.50 \pm 0.01^{\mathrm{e}}$ \\
\hline
\end{tabular}

flour

The values are means of triplicate determination with standard deviation. Superscript with different alphabets in the same column differ significantly $(\mathrm{p}<0.05)$

\section{CONCLUSION}

Inference can be drawn that traditional processing methods reduce the antinutritional components in a significant amount. Germination and fermentation were found to be more effective than roasting and soaking when considering antinutrients reduction (more than 50\%). Germination enhanced the phytochemicals (polyphenols and flavonoids) by more than $25 \%$ while the fermentation process increased by more than $50 \%$. The anti-oxidant activity was increased by more than $50 \%$ during germination and fermentation when compared to the raw one. Functional properties of horse gram flour were also improved by soaking, roasting, germination, and fermentation. It can be concluded that processed horse gram flour was more suitable for product application based on the functional 
property. Further germination and fermentation parameters can be varied to carry out a detailed study on the above parameters.

Acknowledgment: Authors would like to acknowledge the National College of Food Science and Technology, Kathmandu, Nepal for providing all the laboratory facilities.

\section{REFERENCES}

Ademiluyi, A. O., \& Oboh, G. (2011). Antioxidant properties of condiment produced from fermented bambara groundnut (Vigna subterranea L. Verdc). Journal of Food Biochemistry, 35(4), 1145 1160.https://doi.org/10.1111/j.1745-4514.2010.00441.x

Afam Anene, O. C., \& Anyaegbu, E. C. (2016). Effect of germination on the nutritional and anti-nutritional contents of mungbean (Vignaradiata). African Journal of Agricultural Science and Technology (AJAST), 4(7), 801-805.

Agostini, J. D. S., Nogueira, R. B., \& Ida, E. I. (2010). Lowering of phytic acid content by enhancement of phytase and acid phosphatase activities during sunflower germination. Brazilian Archives of Biology and Technology, 53(4), 975-980.http://doi.org/10.1590/S1516-89132010000400028

Agrawal, D., Anubha, U., \& Preeti, S. N. (2013). Functional characteristics of malted flour of foxtail, barnyard and little millets. Annals Food Science and Technology, 14(1), 44-49.

Agume, A., Njintang, N., \& Mbofung, C. (2017). Effect of soaking and roasting on the physicochemical and pasting properties of soybean flour. Foods, 6(2), 12.https://doi.org/10.3390/foods6020012

Ahmed, M. B., Hamed, R. A., Ali, M. E., Hassan, A. B., \& Babiker, E. E. (2006) Proximate composition, antinutritional factors and protein fractions of guar gum seeds as influenced by processing treatments. Pakistan Journal of Nutrition, 5(5), 481-484. http://dx.doi.org/10.3923/pjn.2006.481.484

Akande, K. E., \& Fabiyi, E. F. (2010). Effect of processing methods on some antinutritional factors in legume seeds for poultry feeding. International Journal of Poultry Science, 9(10), 996-1001.http://doi.org/10.3923/ijps.2010.996.1001 Anesini, C., Ferraro, G. E., \& Filip, R. (2008). Total polyphenol content and antioxidant capacity of commercially available tea (Camellia sinensis) in Argentina. Journal of Agricultural and Food Chemistry, 56(19), 9225-9229. http://doi.org/10.1021/jf8022782

Awolu, O. O., Oyebanji, O. V., \& Sodipo, M. A. (2017). Optimization of proximate composition and functional properties of composite flours consisting wheat, cocoyam (Colocasia esculenta) and bambara groundnut (Vigna subterranea). International Food Research Journal, 24(1), 268.

Babalola, R. O., \& Giwa, O. E. (2012). Effect of fermentation on nutritional and anti-nutritional properties of fermenting Soy beans and the antagonistic effect of the fermenting organism on selected pathogens. International Research Journal of Microbiology, 3(10), 333-338.

Bhokre, C. K., Joshi, A. A., \& Rodge, A. B. (2015). Determination of physicochemical and functional properties of different genotypes of horse gram. Asian Journal of Dairy \& Food Research, 34(4), 307-313.

Brito, E. S. D., García, N. H. P., \& Amâncio, A. C. (2002). Effect of polyphenol oxidase (PPO) and air treatments on total phenol and tannin content of cocoa nibs. Food Science and Technology, 22(1), 45-48.http://doi.org/10.1590/S010120612002000100008

Butt, M. S., \& Batool, R. (2010). Nutritional and functional properties of some promising legumes protein isolates. Pakistan Journal of Nutrition, 9(4), 373 379.http://doi.org/ 10.3923/pjn.2010.373.379

Chang, C. C., Yang, M. H., Wen, H. M., \& Chern, J. C. (2002). Estimation of total flavonoid content in propolis by two complementary colorimetric methods. Journal of Food and Drug Analysis, 10(3), 178-182.

Charlton, A. J., Baxter, N. J., Khan, M. L., Moir, A. J., Haslam, E., Davies, A. P. \& Williamson, M. P. (2002). Polyphenol/peptide binding and precipitation. Journal of Agricultural and Food chemistry, 50(6), 1593 1601.http://doi.org/10.1021/if010897z

Chinma, C. E., \& Igyor, M. A. (2007). Micronutrients and anti-nutritiona contents of selected tropical vegetables grown in South East, Nigeria. Nigerian Food Journal, 25(1), 111-116.http://dx.doi.org/10.4314/nifoj.v25i1.33659

Chinma, C. E., Abu, J. O., \& Abubakar, Y. A. (2010). Effect of tigernut (Cyperus esculentus) flour addition on the quality of wheat-based cake. International Journal of Food Science \& Technology, 45(8), 1746 1752.https://doi.org/10.1111/j.1365-2621.2010.02334.x

Dave, S., Yadav, B. K., \& Tarafdar, J. C. (2008). Phytate phosphorus and mineral changes during soaking, boiling and germination of legumes and pearl millet. Journal of Food Science and Technology, 45(4), 344.

Desalegn, B. B. (2015). Effect of soaking and germination on proximate composition, mineral bioavailability and functional properties of chickpea flour. Food and Public Health, 5(4), 108 113.http://doi.org/10.5923/j.fph.20150504.02

Devi, R., Chaudhary, C., Jain, V., Saxena, A. K., \& Chawla, S. (2018). Effect of soaking on anti-nutritional factors in the sun-dried seeds of hybrid pigeon pea to enhance their nutrients bioavailability. Journal of Pharmacognosy and Phytochemistry, 7(2), 675-680.
Đorđević, T. M., Šiler-Marinković, S. S., \& Dimitrijević-Branković, S. I. (2010) Effect of fermentation on antioxidant properties of some cereals and pseudo cereals. Food Chemistry, 119(3) 963.http://doi.org/10.1016/j.foodchem.2009.07.049

Durga, K. K. (2012). Variability and divergence in horsegram (Dolichos uniflorus). Journal of Arid Land, 4(1), 71-76. http://doi.org/10.3724/SP.J.1227.2012.00071

Echendu, C. A., Onimawo, I. A., \& Adieze, S. (2004). Production and evaluation of doughnuts and biscuits from maize-pigeon pea flour blends. Nigerian Food Journal, 22(1), 147-153.http://dx.doi.org/10.4314/nifoj.v22i1.33580

Emmambux, N. M., \& Taylor, J. R. (2003). Sorghum kafirin interaction with various phenolic compounds. Journal of the Science of Food and Agriculture, 83(5), 402-407. Journal of the Science of Food and Agriculture, 83(5), 402-407.https://doi.org/10.1002/jsfa.1379

Gernah, D. I., Ariahu, C. C., \& Ingbian, E. K. (2011). Effects of malting and lactic fermentation on some chemical and functional properties of maize (Zea mays). American Journal of Food Technology,6(5), 404 412.http://dx.doi.org/10.3923/ajft.2011.404.412

Greiner, R., Jany, K. D., \& Alminger, M. L. (2000). Identification and properties of myo-inositol hexakisphosphate phosphohydrolases (phytases) from barley (Hordeum vulgare). Journal of Cereal Science, 31(2), 127 139.https://doi.org/10.1006/jcrs.1999.0254

Hiran, P., Kerdchoechuen, O., \& Laohakunjit, N. (2011). Improvement of Nutritional Values of Germinated Kidney Bean by Fermentation. Journal of Agricultural Science, 42(2), 505-508.

Huma, N., Anjum, M., Sehar, S., Issa Khan, M., \& Hussain, S. (2008). Effect of soaking and cooking on nutritional quality and safety of legumes. Nutrition \& Food Science, 38(6), 570-577.https://doi.org/10.1108/00346650810920187

Kanpairo, K., Usawakesmanee, W., Sirivongpaisal, P., \& Siripongvutikorn, S (2012). The compositions and properties of spray dried tuna flavor powder produced from tuna precooking juice.

Khan, A., \& Saini, C. S. (2016). Effect of roasting on physicochemical and functional properties of flaxseed flour. Cogent Engineering, 3(1) 1145566.https://doi.org/10.1080/23311916.2016.1145566

Khandelwal, S., Udipi, S. A., \& Ghugre, P. (2010). Polyphenols and tannins in Indian pulses: Effect of soaking, germination and pressure cooking. Food Research International, 43(2),

530.https://doi.org/10.1016/j.foodres.2009.09.036

Khang, D., Dung, T., Elzaawely, A., \& Xuan, T. (2016). Phenolic profiles and antioxidant activity of germinated legumes. Foods, 5(2), 27 http://doi.org/10.3390/foods5020027

Krishna, K. R. (2010). Agroecosystems of South India: nutrient dynamics, ecology and productivity. Universal-Publishers. https://doi.org/10.1016/j.foodchem.2004.03.040

Lestienne, I., Icard-Vernière, C., Mouquet, C., Picq, C., \& Trèche, S. (2005) Effects of soaking whole cereal and legume seeds on iron, zinc and phytate contents. Food Chemistry, 89(3),

425.https://doi.org/10.1016/j.foodchem.2004.03.040

López-Amorós, M. L., Hernández, T., \& Estrella, I. (2006). Effect of germination on legume phenolic compounds and their antioxidant activity. Journal of Food Composition and Analysis, 19(4), 277

283.https://doi.org/10.1016/j.jfca.2004.06.012

Mahdavi, R., Nikniaz, Z., Rafraf, M., \& Jouyban, A. (2011). Determination and comparison of the total polyphenol contents of fresh and commercial fruit juices. British Food Journal, 113(6), 744-752. https://doi.org/10.1108/00070701111140089

Makande, F.M., Adetutu, A.O., \& Olorunyomi, G.O. (2016). Influence of roasting techniques on chemical composition and physico-chemical properties of sesame (Sesamum indicum) seed flour and oil. Applied Tropical Agriculture 21(2), 25-31.

Melaku, U., Clive, E. W., \& Habtamon, F. (2005). Content of zinc, iron, calcium and their absorption inhibitors in foods commonly consumed in Ethiopia. Journal of Food Composition and Analysis, 18(8), 803-817. https://doi.org/10.1016/j.jfca.2004.09.008

MOAD. 2016. Statistical information on Nepalese Agriculture 2072/2073. Ministry of Agricultural Development Monitoring, Evaluation and Statistics Division, Agri-Statistics Section, Singha Durbar, Kathmandu Nepal, 31-32.

Moktan, K., \& Ojha, P. (2016). Quality evaluation of physical properties, antinutritional factors, and antioxidant activity of bread fortified with germinated horse gram (Dolichus uniflorus) flour. Food Science \& Nutrition, 4(5), 766771.http://doi.org/10.1002/fsn3.342

Murugkar, D. A., Gulati, P., \& Gupta, C. (2013). Effect of sprouting on physical properties and functional and nutritional components of multi-nutrient mixes. International Journal of Food and Nutritional Science, 2(2), 8-15.

Nithya, K. S., Ramachandramurty, B., \& Krishnamoorthy, V. V. (2006). Assessment of anti-nutritional factors, minerals and enzyme activities of the traditional (Co7) and hybrid (Cohcu-8) pearl millet (Pennisetum glaucum) as influenced by different processing methods. Journal of Applied Sciences Research, 2, 1164-1168 
Nwosu, J. (2011). The Effect of Storage Condition on the Rheological/Functional Properties of Soup Thickner Mucuna sloanei (Ukpo). Researcher, 3, 6-10.

Nwosu, J. N., Owuamanam, C. I., Omeire, G. C., \& Eke, C. C. (2014). Quality parameters of bread produced from substitution of wheat flour with cassava flour using soybean as an improver. American Journal of Research Communication, 2(3), 99-118.

Oboh, G., Ademiluyi, A. O., \& Akindahunsi, A. A. (2009). Changes in polyphenols distribution and antioxidant activity during fermentation of some underutilized legumes. Food Science and Technology International, 15(1), 4146.http://doi.org/10.1177/1082013208101022

Ocheme, O. B., Adedeji, O. E., Lawal, G., \& Zakari, U. M. (2015). Effect of germination on functional properties and degree of starch gelatinization of sorghum flour. Journal of Food Research, 4(2), 159.http://dx.doi.org/10.5539/jfr.v4n2p159

Odedeji, J. O., \& Oyeleke, W. A. (2011). Comparative studies on functiona properties of whole and dehulled cowpea seed flour (Vigna unguiculata). Pakistan Journal of Nutrition, 10, 899902.http://dx.doi.org/10.3923/pjn.2011.899.902

Ogodo, A. C., Ugbogu, O. C., Onyeagba, R. A., \& Orji, F. A. (2017). Dynamics of functional properties of sorghum flours fermented with lactic acid bacteria (LAB)-consortium isolated from cereals. International Food Research Journal, 24(6), 2666-2671.

Ogori, A.F., Alimt, T. (2013). Physiochemical quality of homemade flour from dugged well water soaked and malted millet grain. International Journal of Materials, Methods and Technologies, 1(9), 152 -159.

Ogunkoya, M. O., Abulude, F. O., \& Oni, A. B. (2006). Determination of anatomical, proximate, minerals, oxalate, tannin and phytate compositions of Cuban Boa (Epicrates anquifer). Electronic Journal of Environmental Agricultural and Food Chemistry, 5(1), 1161-1166.

Ojha, P., Prajapati, P., \& Karki, T. B. (2018). Soaking and germination effect on bioactive components of fenugreek seeds (Trigonella foenum graecum L.). International Food Research Journal, 25(2), 690-694.

Ojha, P., Adhikari, R., Karki, R., Mishra, A., Subedi, U., \& Karki, T. B. (2018) Malting and fermentation effects on antinutritional components and functional characteristics of sorghum flour. Food Science \& Nutrition, 6(1), 4753.https://doi.org/10.1002/fsn3.525

Onuegbu, N. C., Nworah, K. O., Essien, P. E., Nwosu, J. N., \& Ojukwu, M (2013). Proximate, Functional and Anti-nutritional Properties of Boiled Ukpo Seed (Mucuna flagellipes) Flour. Nigerian Food Journal,31(1), 15.https://doi.org/10.1016/S0189-7241(15)30049-7

Oti, E., \& Akobundu, E. N. T. (2008). Potentials of cocoyam-soybean-crayfish mixtures in complementary feeding. Nigeria Agricultural Journal, 39(1), 137 145.http://dx.doi.org/10.4314/naj.v39i1.3279

Pal, R. S., Bhartiya, A., ArunKumar, R., Kant, L., Aditya, J. P., \& Bisht, J. K. (2016). Impact of dehulling and germination on nutrients, antinutrients, and antioxidant properties in horse gram. Journal of Food Science and Technology, 53(1), 337-347. http://doi.org10.1007/s13197-015-2037-3

Randhir, R., Kwon, Y. I., \& Shetty, K. (2008). Effect of thermal processing on phenolics, antioxidant activity and health-relevant functionality of select grain sprouts and seedlings. Innovative Food Science \& Emerging Technologies, 9(3), 355-364. https://doi.org/10.1016/j.ifset.2007.10.004

Randhir, R., Lin, Y. T., \& Shetty, K. (2004). Stimulation of phenolics, antioxidant and antimicrobial activities in dark germinated mung bean sprouts in response to peptide and phytochemical elicitors. Process Biochemistry, 39(5), 637-646.https://doi.org/10.1016/S0032-9592

Reddy, N. R. (2001). Occurrence, distribution, content, and dietary intake of phytate. In Food Phytates (pp. 41-68). CRC Press.

Rodríguez, D. A., Sulabo, R. C., González-Vega, J. C., \& Stein, H. H. (2013) Energy concentration and phosphorus digestibility in canola, cottonseed, and sunflower products fed to growing pigs. Canadian Journal of Animal Science, 93(4), 493-503. http://doi.org/10.4141/CJAS2013-020

Saxena, A. K., Chadha, M., \& Sharma, S. (2003). Nutrients and antinutrients in chickpea (Cicer arietinum L.) cultivars after soaking and pressure cooking. Journal of Food Science and Technology, 40(5), 493-497.

Schons, P. F., Battestin, V., \& Macedo, G. A. (2012). Fermentation and enzyme treatments for sorghum. Brazilian Journal of Microbiology, 43(1), 8997.https://doi.org/10.1590/S1517-83822012000100010

Shimelis, E. A., \& Rakshit, S. K. (2007). Effect of processing on antinutrients and in vitro protein digestibility of kidney bean (Phaseolus vulgaris L.) varieties grown in East Africa. Food Chemistry, 103(1), 161172.http://doi.org/10.1016/j.foodchem.2006.08.005

Shrestha, A. K., Dahal, N. R., \& Ndungutse, V. (2010). Bacillus fermentation of soybean: A review. Journal of Food Science and Technology Nepal, 6, 1-9.
Siddhuraju, P., \& Becker, K. (2001). Effect of various domestic processing methods on antinutrients and in vitro protein and starch digestibility of two indigenous varieties of Indian tribal pulse, Mucuna pruriens var. utilis. Journal of Agricultural and Food Chemistry, 49(6), 3058-3067. http://doi.org/10.1021/if001453c

Sigdel, A., Ojha, P., \& Karki, T. B. (2018). Phytochemicals and syneresis of osmo-dried mulberry incorporated yoghurt. Food Science \& Nutrition, 6(4), 1045-1052.https://doi.org/10.1002/fsn3.645

Simpson, T. S., Savage, G. P., Sherlock, R., \& Vanhanen, L. P. (2009). Oxalate content of silver beet leaves (Beta vulgaris var. cicla) at different stages of maturation and the effect of cooking with different milk sources. Journal of Agricultural and Food Chemistry, 57(22), 10804 10808.http://doi.org/10.1021/jf902124w

Sodani, S. N., Paliwal, R. V., \& Jain, L. K. (2005). Phenotypic stability for seed yield in rainfed horsegram [Macrotyloma uniflorum (Lam.) Verdc.]. Arid Legumes for Sustainable Agriculture and Trade (Vol. 2), 4(53.336), 340.

Sreerama, Y. N., Sasikala, V. B., \& Pratape, V. M. (2008). Nutritiona implications and flour functionality of popped/expanded horse gram. Food Chemistry, 108(3), 891-899.https://doi.org/10.1016/j.foodchem.2007.11.055

Sreerama, Y. N., Sashikala, V. B., Pratape, V. M., \& Singh, V. (2012). Nutrients and antinutrients in cowpea and horse gram flours in comparison to chickpea flour: Evaluation of their flour functionality. Food Chemistry, 131(2), 462-468 http://doi.org/10.1016/j.foodchem.2011.09.008

Sreeramulu, G., Srinivasa, D. S., Nand, K., \& Joseph, R. (1996). Lactobacillus amylovorus as a phytase producer in submerged culture. Letters in Applied Microbiology, 23(6), 385-388.https://doi.org/10.1111/j.1472 765X.1996.tb01342.X

Tarzi, B. G., Gharachorloo, M., Baharinia, M., \& Mortazavi, S. A. (2012). The effect of germination on phenolic content and antioxidant activity of chickpea. Iranian Journal of Pharmaceutical Research, 11(4), 1137-1143.

Tiwari, A. K., Manasa, K., Kumar, D. A., \& Zehra, A. (2013). Raw horse gram seeds possess more in vitro antihyperglycaemic activities and antioxidant properties than their sprouts. Nutrafoods, 12(2) 54.http://doi.org/10.1007/s13749-013-0012-Z

Vadivel, V., Stuetz, W., Scherbaum, V., \& Biesalski, H. K. (2011). Total free phenolic content and health relevant functionality of Indian wild legume grains: Effect of indigenous processing methods. Journal of Food Composition and Analysis, 24(7), 935-943. https://doi.org/10.1016/j.jfca.2011.04.001

Valencia, Ulf Svanberg, Ann-Sofie Sandberg, Jenny Ruales, S. (1999) Processing of quinoa (Chenopodium quinoa, Willd): effects on in vitro iron availability and phytate hydrolysis. International Journal of Food Sciences and Nutrition, 50(3), 203-211. https://doi.org/10.1080/096374899101247

Watanabe, N., Fujimoto, K., \& Aoki, H. (2007). Antioxidant activities of the water-soluble fraction in tempeh-like fermented soybean (GABAtempeh). International Journal of Food Sciences and Nutrition, 58(8), 577 587.https://doi.org/10.1080/09637480701343846

Wedad, H. A., El Tinay, A. H., Mustafa, A. I., \& Babiker, E. E. (2008). Effect of fermentation, malt-pretreatment and cooking on antinutritional factors and protein digestibility of sorghum cultivars. Pakistan Journal of Nutrition, 7(2), 335-341.http://doi.org/10.3923/pjn.2008.335.341

Weese, J. S., Weese, H. E., Yuricek, L., \& Rousseau, J. (2004). Oxalate degradation by intestinal lactic acid bacteria in dogs and cats. Veterinary Microbiology, 101(3), 161-166.https://doi.org/10.1016/j.vetmic.2004.03.017

Woffenden, H. M., Ames, J. M., Chandra, S., Anese, M., \& Nicoli, M. C. (2002) Effect of kilning on the antioxidant and pro-oxidant activities of pale malts. Journal of Agricultural and Food Chemistry, 50(17), 4925-4933.

Wu, Z., Song, L., \& Huang, D. (2011). Polyphenolic antioxidants and phytoalexins changes in germinating legume seeds with food grade fungal Rhizopus oligoporus. In 12th Asian Food Conference (pp. 16-18).

Zhang, M., Chen, H., Li, J., Pei, Y., \& Liang, Y. (2010). Antioxidant properties of tartary buckwheat extracts as affected by different thermal processing methods. LWT-Food Science and Technology, 43(1), 181 185.https://doi.org/10.1016/j.lwt.2009.06.020

Zhu, F., Cai, Y. Z., Bao, J., \& Corke, H. (2010). Effect of $\gamma$-irradiation on phenolic compounds in rice grain. Food Chemistry, 120(1), 74-77. https://doi.org/10.1016/j.foodchem.2009.09.072 